\title{
Present status and development of algal pulp for hand-made paper making technology: a review
}

\begin{abstract}
Unwanted blooms of algae throughout the World are not entirely without a positive side. Algae as a raw material for paper making are an innovative solution to Global environmental issues dealing with deforestation and global warming. Algae contain cellulose and hemi-cellulose but no lignin. Thus, they are suitable as raw materials for paper pulp, to be used as wood substitutes but algae alone cannot prove a sole substitute for making paper of good quality. This review tries to summaries the pros and cons of algal paper making along with a thorough description of the additives and various ratios and roles of different additives that can be combined with algal pulp for paper making; besides a critical viewpoint on the pre- and post- preparatory techniques used so far for overall development of the process. Commercialization of the process for development of algal pulp for handmade paper technology has also been discussed with a reference to patent development and evaluation of the Indian Handmade paper industry.
\end{abstract}

Keywords: algae, pulp, paper, additives, techniques, commercialization
Volume 8 Issue I - 2018

\author{
Piyali Mukherjee,' Jai Prakash Keshri² \\ 'Department of Biotechnology, University of Burdwan, India \\ ${ }^{2}$ Department of Botany, University of Burdwan, India
}

\begin{abstract}
Correspondence: Jai Prakash Keshri, Professor at the Department of Botany, DBT-Coordinator at the Department of Biotechnology, The University of Burdwan, Golapbag more, Burdwan-7 I3 I04,West Bengal, India, Email keshrijp@gmail.com
\end{abstract}

Received: May 28, 2017 | Published: January 08, 2018

\section{Introduction}

Algae are highly diverse in their habitat and properties: unicellular such as Chlorella $s p .{ }^{1}$ and the diatoms, to multi-cellular forms, such as the giant kelp, a large brown alga. Algae are eukaryotes though Cyanobacteria or Blue-green algae (like Lyngbya), ${ }^{2}$ are Prokaryotic; but some researchers don't consider Cyanobacteria as algae, ${ }^{3,4}$ Algal Collection of the US National Herbarium (National Museum of Natural History 2008) consists of approximately 320,500 dried specimens, which, although not exhaustive, gives an idea of the order of magnitude of the number of algal species (that number remains unknown). Algae play a promising role in carbon sequestration ${ }^{5}$ and accounts for $50 \%$ of global photosynthesis. ${ }^{6}$ Algae grow fast and efficiently absorb solar energy by means of major antenna pigments like chlorophylls, phycobiliproteins and carotenoids to convert it to chemical energy as triacylglycerols. The role of algae in Greenhouse gas diminution is inevitable. On the other hand, Algae growing in paddy fields have become an unwanted nuisance for the local farmers as the weeds compete for the soil nutrients and a lot of energy and labour is wasted in removal of these weeds through hand-picking or manual efforts. It was reported that after fertilizer applications (ammonium sulfate), Spirogyra ${ }^{7}$ and Euglena ${ }^{8}$ was so abundant that rice farmers had to inter-fill their crops to prevent algae from smothering their rice plants. ${ }^{9}$ Thus, alternate biomass utilization of these algae as substitutes in pulp formulation for the production of handmade paper can pave the way for productive usage of these algae as a means of alternate income generation to the rural people.

The word "paper" is etymologically derived from papyros, Ancient Greek for the Cyperus papyrus plant. ${ }^{10}$ Papyrus is a thick, paper-like material produced from the pith of the Cyperus papyrus plant which was used in ancient Egypt for writing long before the making of paper in China. Before the industrialization of paper production, the most common fibre source was: recycled fibres from used textiles, called rags. The rags were from hemp (Cannabis sativa) plant, ${ }^{11}$ linen and cotton. ${ }^{12}$ Rare Islamic papers were made from hemp or grass stems in Rajasthan, India, colored with vegetable dyes and sheets were burnished by rubbing with a smooth stone (Khadi papers). Invention of paper is mostly credited to the Chinese Eunuch Ts'ai Lun (AD 105), from macerated vegetable fiber. ${ }^{13}$ No definite clue is available as to the date paper was first manufactured in India; though, some people believe paper was invented independently in India in Buddhist times around $250 \mathrm{BC}$.

Archaeological findings at "Gilgit" in the valley of Kashmir indicate that paper was already made in the Himalayas in the sixth century AD. The reports on the grasses: munj (Saccharum munja), discovered by Roxburgh ${ }^{14}$ and bhabar (Ischaemum angustifolium) ${ }^{15}$ show the most promising results. With the discovery of bamboo digestion method, it became a very popular raw material for the steam driven paper plants in India. India had a vast quantity of bamboo forests at that time. With the Bamboo Paper Industry Act of 1925 the colonial government protected the local paper mills. It was on the premises of the Satyagraha ashram in Ahmadabad, India that the first paper mill, the Kalam Kush Paper Mill, based on Gandhian ideas was established. The first paper-machine entered the Indian continent as early as 1832, two years earlier than in the Netherlands.

Dr. William Carey, a Baptist missionary, started to make paper by machine in Serampore. The Khadi Village and Industries Commission (KVIC), founded in 1957, had the difficult task to stimulate and protect the cottage industry, production of fancy papers and training of artisans. Khadi paper mill uses cotton as the raw material and is located just outside the village of Tarihal near Hubli in Karnataka, South India, which is a cotton growing area and Hubli has the biggest open air cotton market in Asia, an amazing sight. Around 1980, the Indian government realised that the demand for paper had outpaced the supply so much that a paper famine was feared in the future. Its true paper consumption per capita in India is very low $(1.4 \mathrm{~kg})$ compared to $285 \mathrm{~kg}$ in the USA. But the economy is prospering. With marketing receiving increasing attention, the Indian papers are now appreciated all over the World. Over the last five years, the export of Indian handmade papers to Amsterdam, Berlin, Brussels, New York, Sydney, Tel Aviv and Tokyo has steadily risen. The time is ripe to search the 
raw materials for development of handmade paper technology in the Indian subcontinent. Thus Indian hand-paper making has great possibilities.

\section{Algae as raw materials for paper}

Ubiquitous distribution and fast growth of algae mark their easy availability as natural resources and possibility of harvesting all year round cuts down the costs involved in farm land cultivation or resource import or transport. ${ }^{16}$ Another important point to consider is the lignin deprivation in algae, although some cases of lignin content in algae (intertidal red algae Calliarthron cheilosporioides) have been documented. ${ }^{17}$ Conventional pulp production from wood as basic material is done through mechanical or chemical process. Mechanical method gives high yield of pulp (90\%) but large amount of energy is wasted to mechanically remove lignin from wood (20-35\% of wood is lignin) whereas in chemical method, yield of pulp is low (50\%). Rice straw, oat/sugarcane residue: bagasse is used as substitute for wood pulp but these also have $12-19 \%$ lignin.

Hence, for development of paper pulp, most energy is wasted on lignin removal. Exploitation of well bonded algal pulp can yield paper that requires no artificial treatments for lignin removal. It was claimed that paper production from red sea weeds algae like Gelidium ${ }^{18}$ (compared to wood pulp) takes shorter time, lower cooking temperature and minimum chemical usage. Compared to wood fibres, algal fibres are finer, more uniform in length, smoother, also have absorbent properties and may not require fillers as determined from lab scale studies undertaken by Prof Dr Phang Siew Moi, director of the university's Institute Of Ocean And Earth Sciences, Malaysia, though no large scale studies have been done. If we consider hemp, it is a high nitrogen crop requiring as much fertilizer as corn: up to $120 \mathrm{lbs} \mathrm{N}$ per acre whereas algae have the ability to fix atmospheric nitrogen and transfer them to plants.

Algae cellulose is different from terrestrial plant cellulose Cellulose in plants is produced by rosettes of synthesizing enzymes extruding ribbons of cellulose strands in crystalline groups excluding water. ${ }^{19}$ The ribbons have less surface area whereas algae cellulose has many times more surface area to volume thus making a very different product. Plant cellulose has specific surface area of 1 square meter per gram while surface area of cellulose from algae Cladophora $s p .{ }^{20}$ can be up to 100 times larger because the cellulose is extruded as single strands. ${ }^{21}$ Furthermore, cellulose from some genera of filamentous green algae exhibit particularly high degree of crystallinity and exhibit preponderance of I-alpha; cellulose as opposed to I-beta cellulose, making them more thermodynamically reactive in comparison to cellulose derived from woody or plant biomass. Another usage of algae in paper can be found in litmus paper made from lichen Rocella tinctoria ${ }^{22}$ that is a symbiosis of fungus (mycobiont) with algae (phycobiont). Cellulose or algae flour from Cladophora algae have been used as reinforcement fibers in construction materials. ${ }^{23,24}$ Raw material evaluation work conducted by the Kumarappa National Handmade paper Institute (KNHPI), India in 2013-14 used Bagasse (Saccharum officinarum), ${ }^{25}$ Coconut palm (Cocos nucifera) ${ }_{,}^{26}$ Jute (Corchorous sp.), ${ }^{27}$ Gunny Bags, Bajra (Pennisetum glaucum), ${ }^{28}$ and Guar plant fiber (Cyamopsis tetragonoloba). ${ }^{29}$ Raw material evaluation for 2014-15 was successfully completed for cow dung, Thor (Euphorbia royleana) fiber $^{30}$ and mustard (Brassica sp.), ${ }^{31}$ shell waste but could not be completed for Turmeric plant (Curcuma longa $)^{32}$ and rayon grade pulp from banana (Musa sp. $)^{33}$ Fiber due to non availability of raw material. ${ }^{34}$ Nordiah et al., ${ }^{35}$ used aquatic plants like Cyperus digitatus, ${ }^{36}$ Cyperus halpan and Cyperus rotundus, ${ }^{37}$ Scirpus grossus,$^{38}$ and Typha angustifolia ${ }^{39}$ for producing handmade paper of permissible strength and quality. The idea of using algae as raw material has not yet been explored yet by the Indian handmade paper making units.

Algae have come up as a valuable raw material for paper besides bioplastics and furniture building in the US and Japan. For designers Jacob Douenias and Ethan Frier, Spirulina ${ }^{40}$ algae also have a role in our homes as lighting and furniture, producing food, fuel, heat and light. Designers Jonas Edvard and Nikolaj Steenfatt have used a new material made from Danish brown Fucus ${ }^{41}$ seaweed and paper to create a chair and a collection of pendant lamps. Thus, algae as a raw material have a long way to go. The continuous lumbering of forests to meet the ever increasing needs of the paper industry is posing an international threat to our environment, partly contributing to global warming. Thus, switch to non-wood material like algae is an urgent issue to consider for the paper industry. Thus algae in paper research pose large possibilities for projects, tests and university-industry cooperations.

Using algae as paper pulp has certain extra advantages. For example:

i. An alga is fast growing and annual crops could be utilized causing no damage to the existing flora thus saving a large part of perennial biomass.

ii. Since algae have great roles in carbon sequestration, it helps to reduce the carbon dioxide levels of atmosphere. When paper making is the aspect to focus on, the tough points with algae are pigment and water removal: bleaching and drying; production and energy costs related to pilot or large scale production (which have not been tested), financing and market value. Paper made from pure algae fibre suffers from poor bursting strength, tearing strength and folding strengths.$^{42}$ Thus, mixing of algal pulp with other raw materials like softwood fibers needs to be exploited to improve paper properties (comparable to Kraft paper).

The Indian handmade paper industry is now facing stringent parameters set forth by developing countries for environment protection. One of the main requirements is dye used for colouring paper should be azo-free as azodyes contain carcinogenic amines. Though vegetable dyes are safe and non-toxic, handmade cardboard industries are causing pollution related problems. Kulshreshtha et al. ${ }^{43}$ studied the mutagenic effect of effluents from cardboard and handmade paper industries to nearby water bodies through Ames test conducted on Salmonella typhimurium TA 98 and TA 100 strains. $^{43}$ To make the rural people aware that alga can be used as a means of alternative livelihood generation is another challenge from the economic perspective.

\section{Natural additives to algal pulp in paper- making}

Improvement of paper quality need pulp improvisations relative to the application of the paper. This involves additives to the algal pulp prior to the cooking process. Rice husk (RH) or hull is the outermost layer of the paddy grain accounting for $20 \%$ of paddy weight having good absorbent properties. High silica contents of rice husk (20$50 \%$ ) increases its Pozzolanic effect that determines cementations' 
properties responsible for increasing the rate at which a material gains strength. ${ }^{44}$ Asia produces about 770 million tons of husks annually obtained from milling of rice grains which can be put to low cost productive usage as algal pulp additive. Saw dust does not have a proper texture and hence is not suitable for writing/painting paper but can e used in making of thick material like egg cartons.

Nature hosts a large repertoire of dyes that can be easily extracted and used in production of coloured paper. For red colour, flowers of Rose (Rosa sp. ${ }^{45}$ or Hibiscus (Hibiscus rosa-sinensis), ${ }^{46}$ Beetroot

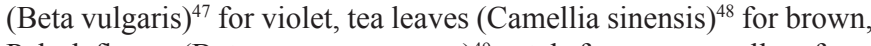
Palash flower (Butea monospermous) ${ }^{49}$ petals for orange, yellow from turmeric and henna leaves (Lawsonia inermis) ${ }^{50}$ for green are some simple home remedies to make natural dyes. Blus et al., ${ }^{51}$ reported 3-carboxypyridinetriazine, hex methyl-diamine and octamethylenediamine as reactive eco-friendly dyes that could bind to hydroxyl groups of cellulose under neutral conditions without changing the strength, optical and dimensional properties of paper; ${ }^{51}$ (Table 1) lists the natural dyes for hand-made paper industry.

Table I Natural dyes from plants and insects that can be used in hand-made paper industry

\begin{tabular}{|c|c|c|c|}
\hline Source & Extraction process & Colour & Reference \\
\hline Dactylopus coccus beetle & Boiling dried beetles in water & Red & 52 \\
\hline $\begin{array}{l}\text { Kerria lacca: a scale insect - Southeast } \\
\text { Asia }\end{array}$ & Colour extracted from resin secreted from the insect & Deep pink & 53 \\
\hline $\begin{array}{l}\text { Haematoxylum campechianum } \\
\text { (Logwood) }\end{array}$ & Colours develop best in slightly hard water & $\begin{array}{l}\text { Purple and shades of grey } \\
\text { with iron }\end{array}$ & 54 \\
\hline Rubia tinctorium (Madder Rich) & Extracted from root & $\begin{array}{l}\text { Range of reds, browns, } \\
\text { purples }\end{array}$ & 55 \\
\hline Punica grantum (Pomegranate) & Skin of the fruit & Red & 56 \\
\hline Acacia arabica (Babool tree) & Microwave assisted extraction from bark & From yellow to red & 57 \\
\hline Bougainvillea glabra & From flower with ivory white bracts & Yellow, green, orange & 58 \\
\hline Tagetes erecta (Marigold) & Extracted from flowers & Golden yellow & 59 \\
\hline Wedelia chinensis (Merril) & Extracted from root & Black & 60 \\
\hline Tectona grandia (Linn) & Extracted from macerated leaves & Red & 61 \\
\hline Peristrophe tinctoria & Whole plant & Red & 62 \\
\hline Nyctanthes arbortristis & Flower tube & Orange & 63 \\
\hline Lawsonia inermis & Macerated leaves & Reddish brown & 64 \\
\hline Erythrina suberosa & Stem bark & Dark brown & 65 \\
\hline Enhydra fluctuans & Leaves & Light green & 66 \\
\hline Curcuma longa & Rhizome & Yellow & 67 \\
\hline Clitoria ternatea & Flower & Blue & 68 \\
\hline Butea monosperma & Flower & Yellow & 69 \\
\hline Bixa orellana & Seed & Orange & 70 \\
\hline Strobilanthes flaccidifolius & Used in Manipur, Nagaland & Blue and black & 71 \\
\hline
\end{tabular}

Plant based natural absorbents were reported from Pinus needles and Lantana camara shoots. ${ }^{72}$ Bamboo shoots have been reported to be a safe and eco-friendly herbal antibacterial absorbent in baby diapers compared to chemical absorbents. ${ }^{73}$ India is vested with the mosquito problem that causes hundreds of deaths each year, infecting people with the deadly Malaria or Encephalitis. Natural mosquito repellents like Nishinda (Vitex negundo) extract, Lemon- Eucalyptus globulus ${ }^{74}$ oil, Citronella (Cymbopogon sp. . $^{75}$ Oil, oil of Lavender (Lavandula $s p.) .{ }^{76}$ Or Neem (Azadirachta indica), ${ }^{77}$ Garlic (Allium sativum), ${ }^{78}$ Apple cider vinegar and camphor can be added to the algal pulp prior to cooking process for manufacture of anti-mosquito fast cards. Addition of saw dust to the pulp can help in production of thick eggcarton like fast cards that will burn for a long time, thus keeping out the mosquitoes.

No doubt such hand-made efforts will hit the Indian mosquito repellent industry due to their eco-friendly and safe nature compared to the smoke evolved from chemical repellents, which harm the respiratory system in humans causing breathlessness and nausea in many cases. Lists of various additives are known to enhance paper quality. Agalite or Talc (Silicate of Magnesia) gives paper a greasy or soapy feel and enables it to take a high finish. AKD (Alkyl ketene dimer) or ASA (Alkyl Succinic Anhydride) are currently used by paper manufacturers as sizing agents although Abietic acid rosin and sodium abietate (rosin soap) in conjunction with Alum (sulphate of alumina) are also used as sizing agents. Though algal pulp may not require fillers or coating, Lime stone or chalk and Dolomite may be used as fillers and Alganic acid (sodium alginate) for coating and surface treatment, if required. Titanium dioxide is also used in the paper industry as coating agent to increase opacity and brightness of paper. Alabaster (Calcium sulphate anhydrate) is used as paper loading material and Albarine (natural sulphate of lime/gypsum/plaster) is 
used in building materials like gypsum boards. The application of caustic soda (sodium hydroxide) in pulping is to increase the $\mathrm{pH}$ in fibre pulp that causes the fibres to smoothen and swell that is important for the grinding/beating process. When handmade paper is the project of concern from the economic point of view, the target is to minimise chemical treatment.

Algal fibres soaked in water are smoother and also have a swelling effect thus negotiating the possibility of alkali treatment. Bleaching with ozone rather than conventional chlorine dioxide reduces costs by $25-30 \%$ with highly improved brightness levels ( $92-$ 93\% ISO); reduction in COD load to wastewater treatment plant by $40 \%$ compared to CP and improved pulp strengths (Xylem Global Inc., NY, USA). Certain dry and weight strength additives may be experimented with. Guar Gum being a natural polymer or carboxy methyl cellulose and cationic starch are better options as dry strength additives compared to polyacrylamide derivatives. Cationic starch gets its positive charge from quaternary salts like EPTAC (2-3 epoxy trimethyl ammonium chlorides) that is also quite costly. Research has opened a new side of possibility to replace costly chemicals like Melamine or Epichlorohydrin known as wet strength additives with one of the most abundant proteins in nature: wheat gluten. ${ }^{79}$ Addition of $2-4 \%$ by weight of agar solutions were prepared by heating agar powder in deionised hot water at $90-95^{\circ} \mathrm{C}$ under rigorous mechanical stirring till the solution turns clear), has shown to increase wet strength of paper.

Cross linker (AmZrCarb) was added to the agar solution 30seconds prior to spraying on the wet paper sheets before pressing. ${ }^{80}$ Soy flour was reacted to DTPA (Diethylenetriaminepentaacetic acid) and sodium hypophosphite, complexed with chitosan to develop a new class of dry strength additives ${ }^{81}$ For many years, the principle binder has been synthetic latex (styrene butadiene latex) but natural binders constitute oxidised potato starch or Dextrin. Gelose prepared from algae designated as agar-agar differs from gelatin, starch and gum from being insoluble in cold water and greater gelatinizing power Gelose contains $42.7 \%$ carbon, $5.7 \%$ hydrogen and $51.4 \%$ oxygen that swells up in cold water and dissolves completely in boiling water to form a jelly 500 times the weight of water to the amount of gelose added, on cooling. Advantage of Gelose is that it imparts a body and gloss to fabrics without stiffening them - a defect with starch and dextrin.

9\% Gelatin besides soy protein, zein, pectin and Salix lignin with Horseradish peroxidase provided significantly higher tear strength $(>900 \mathrm{~g})$ than commercial binders used in CP $(>=700 \mathrm{~g}){ }^{83}$ Corn starch is also a good option but may reduce ink absorption capacity of paper and has been documented in bioplastic research (Patent-US 5288318A). Cow dung, newspaper waste and wheat flour have also been shown to act as natural binders. ${ }^{84}$ Thus possibility of improvising various additive combination ratios remains the main area of challenge in paper quality and design.

\section{Hand-made paper technology: process development}

There are a few reports on the use of green algae as an alternative to wood pulp in paper manufacture. "Shiro Algae Carta"-was a type of paper produced in the European LIFE project to remove algal clogging of a Vincentian lagoon, dating back to the early $90 \mathrm{~s}$. The manufacturing process of Shiro Alga Carta is patented by Favini. The raw algae were first washed, dried and milled in a paper mill to obtain seaweed flour. The flour was mixed with FSC (Forest Stewardship
Council) fibres and cooked with water at $100^{\circ} \mathrm{C}$ for two hours resulting in a boiling jelly that sets into a thin film.

It has been reported that the alginic acid of polysaccharide extracted from the sea weed, such as the giant kelp (a brown algae) and wood pulp were mixed and made into radio cone paper (Paper and Pulp Technic Times, February, 1968, by Yoshio Kobayashi). Another method produced cellulose acetate using acetic acid bacteria as a source of pulp, containing substantially no lignin. (Japanese Patent Provisional Publication No. 212295/1986 or 61-212295). Rhizoclonium $s p .{ }^{85}$ was shown to be a good source of paper pulp in Taiwan ${ }^{42}$ but no color or optical property was evaluated and large scale process was also not done to determine economic feasibility. Cooking pre-beaten pulp with $20 \% \mathrm{NaOH}$ at for $30-120$ min gave high algal pulp yields (70-80\%). This cooking process was sulphur-free, but the water requirement was high. There is another non-wood pulp production method in which pulp is produced from algae including green, red, yellow algae, etc., such as Spirogyra, ${ }^{7}$ Chaetophora, ${ }^{86}$ Ulothrix ${ }^{87}$ Coralline ${ }^{88}$ Tribonema,${ }^{89}$ etc. (Japanese Patent Provisional Publication No. 38901/1979 or 54-38901). Paper from rhizoidal filaments of red algae Gelidium amansii and Gelidium corneum were reported by Seo et al. 2010a. ${ }^{90}$

For a basis weight of $60 \mathrm{~g} / \mathrm{m}^{2}, 90 \%$ opacity was observed in pulpsheets made from red algae fibers whereas wood fibers gave 70$80 \%$ opacity. ${ }^{91}$ Previous work includes addition of other fibre sources to algal pulp but this invention used algae as the sole source of fibre although chemical bleaching with ozone or chlorine and acid/alkali treatment was employed. There is a method of pulp production using a combination of physical and chemical treatment of angiosperm, such as Brazilian waterweed (Japanese Patent Provisional Publication No. 1319/1980 or 55-1319). Another method describes bleaching through light irradiation or chemical treatment of Ulothrix, ${ }^{87}$ Hydrodictyon ${ }^{92}$ and Tribonema, ${ }^{89}$ and freshwater algae, such as blue algae, yellow flagellous plant, and Chlorophyta ${ }^{93}$ and production of paper sheet singly or by mixing these with other materials for pulp (Japanese Patent Provisional Publication No. 520/1989 or 54-520).

Cardboard and paper manufacture from Sea weeds have also been reported (US patent 1367279 and US1675244). Pegasus Research Inc, US - Owns a patented process for the production of pulp and paper made from Red Algae (Gracilaria and Gelidium elegans), ${ }^{94,95}$ "Plant pack" funded by the European Commission (2012-2014), was a project undertaken to replace conventional petroleum derived waxes and polymers as food-pack coatings in cardboard or paper with a sustainable, eco-friendly food-pack coating material derived from seaweed.

Development in terms of sustainable technology for manual paper sheet pressing was undertaken. Figure 1 demonstrates a hand-operated hydraulic press designed in our laboratory for the pressing of handmade paper sheets made from algae. Upper chamber/plate had heating coils linked to the temperature controller enabled with temperature range of $50^{\circ} \mathrm{C}$ to $170^{\circ} \mathrm{C}$. Lower chamber was a stainless steel plate slightly larger than A4 size paper. Heating coils were not set in the lower plate to ensure insulation and safety as wet paper sheets were to be placed on this plate.

The lower plate could be hand-pulled on the water drainage chamber to facilitate sheet loading and unloading. Another advantage of the chamber was that it could collect any residual water that might drip from the paper sheets after pressing. The Hydraulic tank had an aperture at its base for adjustment of the hand pump. Rotation of the pump anti-clockwise within the aperture moved the lower plate up for 
pressing. Anticlockwise movement of hand-pump within the aperture brought the lower plate down in a smooth hydraulic movement. 50 sheets could be pressed at a time with a maximum pressure load of 5 tons in this press.

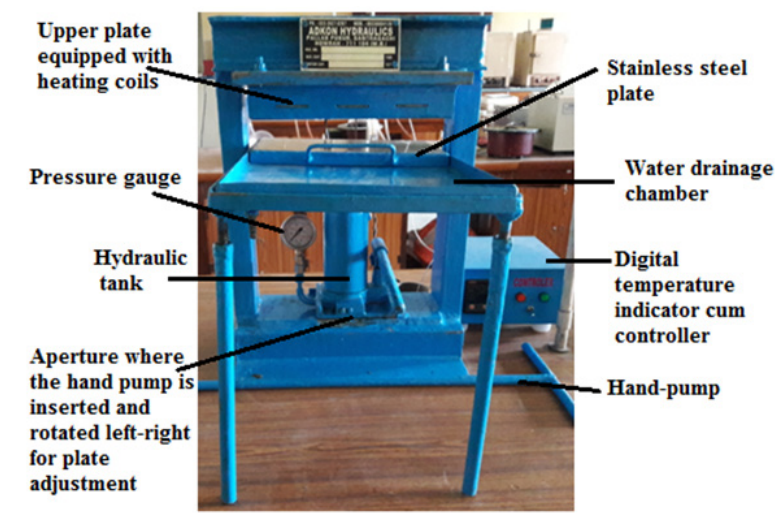

Figure I A simple hand-operated Hydraulic press designed in our lab for pressing of hand-made paper sheets from algae.

\section{Suitability of algae pulp as an alternative to conventional pulp}

Ververis et al. ${ }^{95}$ attributed presence of proteins and chitin in algae as factors responsible for significant improvement in mechanical properties of paper from algae (A) compared to conventional pulp (CP) ${ }^{96}$ as presented in Table 2 . Although, brightness was adversely affected by chlorophyll in algae; the cost of raw materials was $45 \%$ lower than that of conventional pulp. Addition of never-dried Rhodophyta algae fibers to CP provided pulp sheets with improved tensile and burst strength properties, with minimal deterioration in Canadian standard freeness $(>200 \mathrm{ml})$.

A pulp sheet comprising 30 weight percent never-dried macroalgae pulp fibers, had moisture content less than about 15 percent, a basis weight of at least about 150 grams per square meter and an MD Tensile Index of $10-40 \mathrm{Nm} / \mathrm{g} .{ }^{99}$ Breaking length of red algae pulp $(4.75 \mathrm{Km})$ sheets were found to be similar to CP made from Hanji fibers $(4.65 \mathrm{Km})$ with marked improvements in brightness for red algae pulp (35sec) compared to Hanji $(3 \mathrm{sec}) .{ }^{100}$

$10 \%$ red algae fibers added to $70 \% \mathrm{CP}$ hardwood pulp resulted in a tensile index of $29.87 \mathrm{~N} * \mathrm{~m} / \mathrm{g}$ and Burst index of $1.75 \mathrm{KPa}$; whereas $20 \%$ red algae pulp without any hardwood fibers but $80 \%$ straw pulp gave considerable increased tensile index of $58.10 \mathrm{~N} * \mathrm{~m} / \mathrm{g}$ and Burst index of $3.02 \mathrm{KPa}^{101}$ Shi et al., ${ }^{102}$ also demonstrated marked improvement in CP on addition of Gelidium corneum, Gelidium amansii, Gelidium robustum, Gelidium chilense, and Gelidium asperum pulp: CP (70\% hardwood pulp with $30 \%$ OCC-old corrugated containers) gave a tensile index of $17.3 \mathrm{~N} . \mathrm{m} / \mathrm{g}$ and ring crush of $0.46 \mathrm{KN} / \mathrm{m}$. Pulp-sheets containing $20 \%$ red algae fibers with $40 \%$ wheat straw and $40 \%$ blended Kenaf (Hibiscus cannabinus) gave a ring crush of $3.78 \mathrm{KN} / \mathrm{m}$ and tensile index of $45.9 \mathrm{~N}$. m/g that further increased to $73.6 \mathrm{~N} . \mathrm{m} / \mathrm{g}$ on addition of $80 \%$ corn Stover with $20 \%$ red algae fibers. Additives of $0.2 \%$ Carrageenans (sulfated gums) found in red algae, to pulpsheets were shown to increase tensile index by $13.53 \%$ and precipitated calcium carbonate (PCC) retention increased by $57.06 \%{ }^{103}$ Hand sheets containing CP (hardwood kraft pulp) and Cladophora algal cellulose showed almost no improvement in tensile strength and folding endurance but improved dimensional stability and comparatively higher Young's modulus although bacterial cellulose improved tensile strength and folding endurance as well. ${ }^{104}$ On the other front, Cladophora cellulose has a very high degree of crystallinity ( $118.7 \mathrm{~nm}$ crystalline length and $11.3 \mathrm{~nm}$ crystalline width) that imparts inertness to chemical reactions, maintains a high specific surface area on drying without any hornification or agglomeration, causing an improved redispersibility in comparison to CP (Eucalyptus pulp) having crystalline width of only $3.6 \mathrm{~nm}$ and crystalline width of only $37 \mathrm{~nm} .{ }^{105-107}$ Red algae biomass of Gelidium elegans have also been shown to contain nanocellulose fibers of high crystallinity index $(73 \%)$ suitable for nanocomposite materials. ${ }^{108}$

Table 2 Comparative evaluation of paper strength properties of conventional pulp versus algal pulp as cited in literature

\begin{tabular}{llllll}
\hline Paper pulp & $\begin{array}{l}\text { Breaking length } \\
(\mathbf{K m})\end{array}$ & $\begin{array}{l}\text { Bursting strength }(\mathbf{K P a} \\
\left.\mathbf{m}^{2} / \mathbf{g}\right)\end{array}$ & Tear resistance $\left(\mathbf{m N} \mathbf{~ m}^{2} / \mathbf{g}\right)$ & Brightness $(\%)$ & References \\
\hline Conventional pulp & 1.63 & 0.75 & 97 & 85 & 96 \\
Algae & 2.5 & 1.7 & 106 & 60 & 97,98 \\
Closterium & 5 & 1.8 & 45 times folding endurance & 75 & \\
\hline
\end{tabular}

Machmud et al., ${ }^{109}$ showed tensile properties of the sheets made of Gracilaria sp. such as tensile elongation, ultimate strength and absorbed energy were even better than those of both the recycled and office copy paper sheets made from conventional wood pulp. Elongation $\%$ of pulpsheets from Gracilaria $s p$. was $10 \%$ and Eucheuma cottonii was $12.5 \%$ compared to only $3-4 \%$ for CP (A4 office paper). Ultimate tensile strength of pulpsheets from Gracilaria $s p$. was $10 \mathrm{Kgf} / \mathrm{cm}^{2}$ and Eucheuma cottonii was $49 \mathrm{Kgf} / \mathrm{cm}^{2}$ compared to $18 \mathrm{Kgf} / \mathrm{cm}^{2}$ for $\mathrm{CP}$ (recycled A4). Further, energy absorption for Gracilaria sp. pulpsheets was $2 \mathrm{Kgf.cm}$ and $5 \mathrm{Kgf.cm}$ for Eucheuma cottonii sheets compared to only $1 \mathrm{Kgf.cm}$ for CP (A4). The helliclular microfibrillar arrangement in Chara sp. has a low net angle of orientation which was correlated with comparatively increased values of longitudinal elastic stiffness, longitudinal elastic modulus, and standard tensile strength, ${ }^{110-112}$ but with diminished values of percentage stretch and tensile energy absorption. ${ }^{13,114}$ Crystallinity indices of Chara pulp cellulose was 0.80 and Cladophora pulp was 0.92 as compared to 0.89 for CP (softwood pulp). ${ }^{115}$

( $20 \%$ of $\mathrm{NaOH}$ treated samples of Rhizoclonium and Pithophora had tensile strengths, burst strengths and tear strengths in the range of $150 \%, 250 \%$, and $165 \%$ greater than hand sheets made from the base pulp alone ${ }^{116}$ Tissue papers made from $10-30 \%$ algae fibers with $\mathrm{CP}$ have significant increased wet strength (specific absorption $>10 \mathrm{~g} / \mathrm{g}$ ) with a geometric mean tensile strength between 600-4500grams (force) per 3 inches of sample width. ${ }^{117}$ Mazur, 2015, ${ }^{118}$ proposed fungal mycelia of Saprolegnia ferax would have an ultimate tensile strength of $41 \mathrm{~N}$ (as compared to $528 \mathrm{~N}$ for a standard copy paper, roughly $1 / 10$ th the tensile strength of standard weight $\left(60 \mathrm{~g} / \mathrm{m}^{2}\right)$ 
copy paper). Additionally pulpsheets from incorporation of fibers from Ulva sp. greatly enhanced tear resistance and elongation, but diminished tensile and burst properties. ${ }^{119}$

Enhanced mechanical properties (flexural and tensile modulus of $70 \%$ and $86 \%$ ) were found when $56 \%$ algae fiber was used for the compression-molded laminates composite but volume of porosity was $11 \%$ due to lack of compression in some of the fibers. ${ }^{120}$ Although some properties may be decreased with algal pulp in some cases, it should be noted that they are still acceptable for many applications, and using algae fibers implies notorious savings in terms of costs of raw materials, energy, reagents, and equipment

\section{Conclusion}

The use of algae as an alternative source of paper production will meet the needs of environment issues like deforestation and global warming. Indian handmade paper Industry primarily uses cotton rags, waste paper and waste Kraft as raw materials. Some steps have been initiated for the utilization of straws, jute, rice husk and grasses though further research for incorporating other raw materials like algae need to be undertaken. Although some work on the lab scale has been done in Japan and US, paper from algae has a long way to go in process and quality development for commercialization. The market value of hand-made paper has thrived well and found their way into the art crafts industry and furniture industry. Use of algae hand-made paper are making way into extraordinary fields of applications and more seems to come in future.

For example, the recent use of thin hand-made paper from Cladophora algae as conducting polymer coatings in batteries have been found to store 50-200\% more charge than other conducting polymer batteries that may give a tough competition to the commercial lithium batteries. Value added products from algae also hold much promise in generating alternative sources of livelihood generation from the economic point of view. Carbon dioxide sequestration, removal and productive utilization of fouling biomass from paddy fields and alternative income generation to the rural people are certain other aspects that may make additional input in bio-remediating environment by direct or indirect means.

\section{Acknowledgements}

The authors are grateful to the Department of Science and Technology (DST), New Delhi, India for the grant of Woman Scientist B scheme to Dr Piyali Mukherjee. The authors also acknowledge the Department of Biotechnology, The University of Burdwan for providing adequate lab and library facility necessary for documentation of this study. This study was funded by the Woman Scientist B Project grant: DST/Disha/SoRF-PM/061/2013 awarded to Dr Piyali Mukherjee, by The Department of Science and Technology (DST), New Delhi, India.

\section{Conflict of interest}

The Authors declare that they have no conflict of interests.

\section{References}

1. Scheffler J. Underwater Habitats. Illumin. 2007;9(4):1-9.

2. Guiry MD, Guiry GM. Lyngbya, Algae Base. World-wide electronic publication. Galway, Ireland: National University of Ireland; 2008.
3. Nabors, Murray W. Introduction to Botany. San Francisco, CA:Pearson Education, Inc: Allaby M editor. Algae The Concise Dictionary of Botany. Oxford, USA: Oxford University Press; 2004. 442 p.

4. Packer M. Algal capture of carbon dioxide, biomass generation as tool for greenhouse gas mitigation with reference to New Zealand energy strategy and policy. Energy policy. 2013;37(9):3428-3437.

5. Morony JV, Ynalvez RA. Algal photosynthesis. Chichester, USA: John Wiley and Sons Ltd; 2009.

6. Morton WE, Hearle JWS. Physical Properties of Textile Fibres. 2nd ed. New York: USA: John Wiley and Sons; 1975. 660 p.

7. Nees von Esenbeck, Christian Gottfried Daniel. Vorlesungen zur entwickelungsgeschichte des magnetischen schlafs und traums, archiv fur den thierischen magnetismus. Hrsg von Dr CA. 1820;7(2):1-70.

8. Adl SM, Simpson AG, Lane CE, et al. The Revised Classification of Eukaryotes. J Eukaryot Microbiol. 2012;59(5):429-493.

9. Subramanian R, Manna GB. Relative response of the rice plant to blue green algae and ammonium sulfate in bulk trials. Curr Sci. 1966;35(19):482-483

10. Jones MB, Milburn TR. Photosynthesis in Papyrus (Cyperus papyrus L). Photosynthetica. 1978;12:197-199.

11. Green G. The Cannabis Breeder's Bible. USA: Green Candy Press; 2005. p. 15-16.

12. Gottsching L, Pakarinen H. Recycled Fiber and Deinking, Papermaking Science and Technology 7. Finland, Fapet Oy; 2000. p. 12-14.

13. Hunter D. Papermaking:The History and Technique of Ancient Craft. New York: Dover publications; 1978. p. 1-5.

14. Robinson TF. William Roxburgh (1751-1815): the founding father of Indian botany. PhD thesis, Edinburgh, UK: The University of Edinburgh; 2003. p. 1-369.

15. Rehm S. Multilingual dictionary of agronomic plants. Netherlands 1994. p. 27-38.

16. Kaushik N, Biswas S. Algae biomass-technology trends and business opportunities. In Shukla JP editor. Technologies for sustainable rural development:having potential of socio-economic upliftment (TSRD-2014). Allied publishers; 2014. p. 36-44.

17. Martone PT, Estevez JM, Lu F, et al. Discovery of lignin in seaweed reveals convergent evolution of cell-wall architecture. Curr Biol. 2009;19(2):169-75.

18. Tronchin EM, Freshwater DW, Bolton JJ, et al. A Reassessment and reclassification of species in the genera onikusa akatsuka and Suhria $\mathrm{j}$ Agardh ex Endlicher (Gelidiales, Rhodophyta) based on molecular and morphological data. Bot. 2002;45(6):548-558.

19. Somerville C. Cellulose synthesis in higher plants. Annual reviews. 2006;22:53-78.

20. Marsin P, Tomasz J. Introductory studies on the morphology of the genus Cladophora from the Gulf of Gdańsk. Ocean Hydrob Studies. 2005;34(3):187-193.

21. Tsekos I. The sites of cellulose synthesis in algae:diversity and evolution of cellulose-synthesizing enzyme complexes. $J$ Phycol. 2002;35(4):635655 .

22. Robiquet. Essai Analytique des lichens de l'orseille. Annales de chimie et de physique. 1829;42:236-257.

23. Mihranyan A. Cellulose from cladophorales green algae: From environmental problem to high-tech composite materials. J Appl Polymer Sci. 2010;119(4):2449-2460. 
24. Johnson M, Shivkumar S. Filamentous green algae additions to isocyanate based foams. J App Polym Sci. 2004;93:2469-2477.

25. Daniels C, Needham J. In New Guinea. Science and Civilization in China. 1966;6(3):129

26. Pearsall J ed. Coconut. Concise Oxford Dictionary. 10th ed. Oxford: Clarendon Press; 1999.

27. Chittenden FJ, editors. Comprehensive listing of species and how to grow them, RHS Dictionary of Plants plus Supplement. USA: Oxford University Press; 1956.

28. Manning K, Pelling R, Higham T, et al. 4500-year-old domesticated pearl millet (Pennisetum glaucum) from the Tilemsi Valley, Mali:new insights into an alternative cereal domestication pathway. J Archaeol Sci. 2010;38 (2):312-322.

29. Whistler RL, Hymowitz T. Guar: agronomy, production, industrial use and nutrition. West Lafayette, India: Purdue University Press; 1979. p. 101-113.

30. Singh DK, Agarwal RA. Correlation of the Anticholinesterase and Molluscicidal Activity of the Latex of Euphorbia royleana on the Snail Lymnaea acuminate. J Nat Pro. 1984;47(4):702-705.

31. Wang X, Wang H, Wang J, et al. The genome of the mesopolyploid crop species Brassica rapa. Nat Genet. 2011;43(10):1035-1039.

32. Ravindran PN editoor. The genus Curcuma, Boca Raton. FL: Taylor \& Francis; 2007. p. 7-506.

33. Bailey LH. The Standard Cyclopedia of Horticulture. New York, Macmillan, India; 1914. p. 2076-2079.

34. KNHPI (Kumarappa National Handmade Paper Institute), India: Annual report; 2014-2015. p. 1-98.

35. Nordiah B, Muta HZ, Japar SB, Nur AAA. Suitability of aquatic plant fibers for handmade papermaking. Int J Polym Sci. 2015. p. 1-9.

36. Bhargavan P. Cyperaceae. In: Henry AN, et al. editors. Flora of Tamil Nadu, India Botanical Survey of India. India; 1989. p. 1-171.

37. Huygh W, Larridon I, Reynders M, et al. Nomenclature and typification of names of genera and subdivisions of genera in Cypereae (Cyperaceae):Names of genera in the Cyperus. Clade Taxon. 2010;59(6):18831890 .

38. Gupta AK. Actinoscirpus grossu. The IUCN Red List of Threatened Species 2011. e.T169004A6560789; 2011.

39. Stuckey RL, Salamon DP. Typha angustifolia in North America: masquerading as a native. Am J Bot. 1987. p. 74:757.

40. Gomont M. Monographie des Oscillariées (Nostocacées Homocystées). Deuxième partie.-Lyngbyées. Annales des Sciences Naturelles Botanique Série. 9182;7(16):91-264.

41. Stegenga H, Bolton JJ, Anderson RJ. Seaweeds of the South African West Coast, Contributions from the Bolus Herbarium. South Africa: University of Cape Town; 1997. p. 18-640.

42. Chao KP, Yu CS, Chung SC. Feasibility of utilizing Rhizoclonium in pulping and papermaking. J Appl Phycol. 2000;12:53-62.

43. Kulshreshtha S, Mathur N, Bhatnagar P. Handmade paper and cardboard Industries:in health perspectives. Toxicol Ind Health. 2011;27(6):51521.

44. Jauberthie R, Rendell F, Tamba S, et al. Origin of the Pozzolanic effect of rice husks. Construction and building materials. 2000;14:419-423.

45. Saati EA, Simon BW, Yunianta, et al. Isolation of red rose anthocyanin pigment and its application to inhibit lipid oxidation in yoghurt. $J$ Agric Sci Technol. 2011;1:1192-1195.
46. Vankar PS, Srivastava J. Comparative study of total phenol, flavonoid contents and antioxidant activity in canna indica and hibiscus rosa sinensis, prospective natural food dyes. Int J Food Eng. 2008;4(3):1-16.

47. Linnaeus C. First description of Beta vulgaris, Species Plantarum. Tomus. $1753 ; 1: 222$

48. Stafleu FA, Cowan RS. Taxonomic literature: A selective guide to botanical publications and collections with dates, commentaries and types. 2nd ed. Utrecht: Bohn, Scheltema \& Holkema; 1976. 1 p.

49. Huxley A editor. New RHS Dictionary of Gardening. London: Macmillan press; 1992. p. 664-665.

50. Bailey LH, Bailey EZ. Hortus Third: A concise dictionary of plants cultivated in the United States and Canada. New York, Macmillan; 1976. 1290 p.

51. Blus K, Czechowski J, Kozirog A. New eco-friendly method for paper dyeing. Fibers and textiles in eastern Europe. 2014;5(107):121-125.

52. Phipps E. Cochineal red: the art history of a color. Metropolitan Museum of Art Bulletin. 2010;67(3):1-22.

53. Wouters J, Verhecken A. The coccid insect dyes:Hplc and computerized diode-array analysis of dyed yarns, Stud. Conserv. 1989;34(4):189-200.

54. Hofenk G, Judith H. The Colorful Past: Origins, Chemistry and Identification of Natural Dyestuffs. London: Archetype Books; 2004. p. 1-235.

55. Bhardwaj HC, Jain KK. Indian Journal of History of Science, New Delhi. Indian National Science Academy. 1982;17 (11):70-81.

56. Osborne R, Pavey D. On Colors 1528: A Translation from Latin. Parkland, Fla, USA: Universal Publishers; 2003.

57. Saakshy Madhu A, Ajendra Jain RK, et al. Acacia arabica - a source of natural dye for handmade paper making. Int $J$ Engg Res and tech. 2013;2(12):2237-2245.

58. Gokhale SB, Tatiya AU, Bakliwal SR, et al. Natural dye yielding plants in India. Nat Prod Rep. 2004;3(4):228-234.

59. Cantrill R. Lutein from Tagetes erecta, Chemical and Technical Assessment. 63rd JECFA; 2004. p. 1-5.

60. Das PK, Mondal AK. The dye yielding plants used in traditional art of "Patchitra" in Pingla and mat crafts in Sabang with prospecting proper medicinal value in Paschim Medinipur district, West Bengal, India. Int J Life Sc Biotech Pharm Res. 2012;1(2):158-171.

61. Potsangbam L, Ningombam S, Laitonjam WS. Natural dye yielding plants and indigenous knowledge of dyeing in Manipur, Northeast India. Indian J Tradit Knowle. 200;7(1):141-147.

62. Lawarence B, Mahesh S, Murugan G, et al. Ethnic knowledge of dye yielding plants used by the Kani Tribes of Ponmudi Hill: a case study. Indo Am J Pharm Res. 2015;5(7):2611-2616.

63. Lal JB. Constitution of the coloring matter of Nyctanthes arbortristis. Identity of Nyctanthin with $\alpha$-crocetin 2, Proceedings of the National Institute of Sciences; 1936. p. 1-57.

64. Gaur RD. Traditional dye yielding plants of Uttarakhand, India, Nat Prod Rep 7(2):154-165.

65. Iqbal S, Taiyaba AN (2014) Natural dyes:their sources and ecofriendly use as textile materials. J Environ Res Dev. 2008;8(3A):683-666.

66. Datta SC, Banerjee AK. Useful weeds of west Bengal rice fields. Econ Bot. 1978;3(3):297-310.

67. Bhatti IA, Sahid A, Jamal MA, et al. Influence of gamma radiation on the color strength and fastness properties of fabric using turmeric (Curcuma lsonga L.) as natural dye. Radiat Phys Chem. 2010;79(5):622-625. 
68. Wongcharee K, Meeyoo V, Chavadej S. Dye-sensitized solar cell using natural dyes extracted from rosella and blue pea flowers. Sol Energ Mat Sol C. 2007;91(7):566-571.

69. Sinha K, Saha PD, Datta S. Extraction of natural dye from petals of Flame of forest (Butea monosperma) flower: Process optimization using response surface methodology (RSM). Dyes and Pigments. 2012;94(2):212-216.

70. Rao PG, Prabhakara A, Satyanarayana, et al. Effect of storage on the stability of water soluble annatto dye formulation in a simulated orange-RTS beverage model system. LWT-Food Science and Technology. 2002;35(7):617-621.

71. Sharma H, Manoranjan A, Devi R, et al. Vegetable dyes used by the Meitei community of Manipur. Indian J Tradit Knowle. 2005;4(1):39-46.

72. Malik DS, Jain CK, Yadav AK. Preparation and characterization of plant based low cost absorbents. J Global Biosc. 2015;4(1):1824-1829.

73. Malarvizhi G. Development of herbal finished baby diapers with bamboo fibre. BEST. Int $J$ Humanities Arts Medicine and sciences. 2015;3(2):41-46.

74. Mulvaney J. Botanising, The axe had never sounded: place, people and heritage of Recherche Bay \& Tasmania ediotrs. Australia: Australian National University; 2006. p. 31-141.

75. Soenarko S. The genus Cymbopogon sprengel (Gramineae). Reinwardtia. 1977;9(3):225-375.

76. Upson T, Andrews S, Kew B. The Genus Lavandula, Royal Botanic Gardens, 456 Yule H, et al. editors. Hobson-Jobson, Neem, The Anglo-Indian Dictionary, Wordsworth; 2004;58(4):1-622.

77. Block E. Garlic and Other Alliums. The Lore and the Science Roy Soc Ch. 2010. pp. 1-480.

78. Ren D, Kaichang L. Development of wet strength additives from wheat gluten. Holzforschung. 2005;59(6):598-603.

79. Elias R. The improvement of paper extensibility, wet and dry strength by spray addition of agar solutions, Paper physics. Nord Pulp Paper Res J. 2014;29(3):434-443.

80. Salam A, Lucian AL, Hasan J. A new class of biobased paper dry strength agents:synthesis and characterization of soy-based polymers. ACS Sustain Chem Engg. 2015;3(3):524-532.

81. Watt G. A dictionary of the economic products of India in A Dictionary of the Economic Products of India. India: Cambridge University Press; 2014. p. 1-597.

82. Flory AR, Requesens DV, Devaiah SP, et al. Development of a green binder system for paper products. BMC Biotechnology. 2013;13:28.

83. Daham S, Amarasinghe ADUS, Senanayak NS. Evaluation of different binding materials in forming biomass briquettes with saw dust. Int J Sci Res Pub. 2015;5(3):1-8.

84. Ramirez ME Santelices B. Catalogo de las algas marinas bentónicas de la costa templada del Pacifico de Sudamerica. Monografias Biológicas Chile. 1991;5:1-440.

85. Schrank FVP. Botanische Rhapsodien. Der Naturforscher (Halle) 1783;19:116-126.

86. Walsh GE. An ecological study of a Hawaiian mangrove swamp. In: Estuaries, et al. editors. Washington, DC: AAAS Publication 83; 1967. p. 420-431.

87. Aguirre J, Perfectti F, Braga JC. Integrating phylogeny, molecular clocks, and the fossil record in the evolution of coralline algae (Corallinales and Sporolithales, Rhodophyta). Paleobiology. 2010;36(4):519.
88. Pearson LC. The diversity and evolution of plants. Boca Raton, Fla: CRC Press; 1995. p. 1-293.

89. Seo YB, Lee YW, Lee CH, et al. Red algae and their use in papermaking. Biores Tech. 2010;101(7):2549-2553.

90. Seo YB, Lee YW, Lee CH, et al. Optical properties of red algae fibers. Industrial and engineering chemistry research. 2010;49(20):9830-9833.

91. Roth AW. Bemerkungen über das Studium der cryptogamischen. Wassergewächse. 1797;1:6-109.

92. Vanden Hoek CVD, Mann DG, Jahns HM. Algae an Introduction to Phycology. Cambridge, USA: Cambridge University Press; 1995. 623 p.

93. Steentoft M, Farham WF. Northern distribution boundaries and thermal requirements of Gracilaria and Gracilariopsis (Gracilariales, Rhodophyta) in Atlantic Europe and Scandinavia. Nord J Bot. 1997;5:87-93.

94. Kützing, Friedrich Traugott. Tabulae phycologicae Oder, Abbildungen der Tange 100 pls. Nordhausen: Gedruckt auf kosten des Verfassers (in commission bei W. Köhne). 1868;18:418.

95. Ververis C, Georghiou K, Danielidis D, et al. Cellulose, hemicelluloses, lignin and ash content of some organic materials and their suitability for use as paper pulp supplements. Bioresource Technol. 2006;98(2):296301.

96. Kaisha MJK. Method of producing pulp. Masayasu C/O Hiroshima Techn. Inst., EP0488486A1; 1992.

97. Liu Z, Li X, Xie W. Carrageenan as a dry strength additive for papermaking. PLoS One. 2017;12(2):1-11.

98. Sakai M, Seto T, Kaneko M, et al. Method of producing pulp from green algae. Mitsubishi Jukogyo Kabushiki Kaisha, US5500086A; 1996.

99. Shi B, Veith MW, Krautkramer CD, et al. High strength macroalgae pulps. Kimberley Clark Worldwide Inc, WO2013175330A1; 2013.

100. Seo YB, Lee MW, Kim YW, et al. Improvements in the physical properties of Hanji by using Red algae pulp. Journal of Korea Technical association of the pulp and paper industry. 2009;41(5):33-37.

101. Shi B, Mleziva MM, Thompson BM, et al. Hybrid Fiber Compositions and Uses in Containerboard Packaging. US20140093704A1; 2012.

102. Shi B, Mleziva MM, Thompson BM, et al. Tree-free fiber compositions and uses in containerboard packing, Kimberley Clark Worldwide Inc. US20140093705A1; 2014.

103. Liu Z, Li X, Xie W. Carrageenan as a dry strength additive for papermaking. PLoS ONE. 2017;12(2):e0171326.

104. Shibazaki H, Kuga S, Onabe F. Mechanical properties of handsheets containing bacterial cellulose. Japan Tappi J. 2009;48(12):1621-1630.

105. Xiang Z, Gao W, Chen L, et al. A comparison of cellulose nanofibrills produced from Cladophora glomerata algae and bleached Eucalyptus pulp. Cellulose. 2015;23(1):493-503.

106. Hua K, Carlsson DO, Alander E, et al. Translational study between structure and biological response of nanocellulose from wood and green algae. RSC Adv. 2014;4:2892-2903.

107. Stromme M, Mihranyan A, Ek R. What to do with all these algae? Mater Lett. 2002;57(3):569-572.

108. Chen YW, Lee HV, Juan JC, et al. Production of new cellulose nanomaterial from red algae marine biomass Gelidium elegans. Carbohydrate polymers. 2016;151:1210-1219.

109. Machmud MN, Fadi F, Faudi Z, et al. Alternative Fiber Sources from Gracilaria Sp and Eucheuma Cottonii for Papermaking. International journal of Science and Engineering. 2014;6(1):1-10. 
110. Mark RE, Gillis PP. The relationship between fiber modulus and S2 angle. Tappi. 1973;56(4):164-167.

111. Page DH, F E1-Hosseiny K Winkler, Lancaster APS. Elastic modulus of single wood pulp fibers. Tappi. 1977;60(4):114-117.

112. Salmon L, Ruvo AD. A model for the prediction of fiber elasticity. Wood and Fiber Science. 1985;7(3):336-350.

113. Morton WE Hearle JWS. Physical Properties of Textile Fibres. 2nd ed. London: Textile Institute \& Heinemann; 1975. p. 265-275.

114. Wainwright SA, WD Biggs JD Currey, Gosline JM. Mechanical Design in Organisms. Princeton: USA: Princeton University Press; 1976. p. $1-423$.

115. Hackney JM, Waterhouse JF, Cook ME, et al. An Investigation of the Structural and Mechanical Properties of Handsheets Containing CellWall Materials from Three Green Algae. Part -1: Characterization of cell wall materials, Cellulose; 1995. p. 1-28.
116. Tarrant LB, Berlowitz A, Tukumo T. Algal pulps and pre-pulps and paper products made there from, Int Technology Management Associates Ltd., WO1994004745A1; 1994.

117. Shannon TG, Shi B, Pelky EE, et al. Tissue products containing microalgae materials, Kimberley Clark Worldwide Inc: US8298374B2; 2012.

118. Mazur R. Mechanical properties of sheets comprised of mycelium: a paper engineering perspective. department of environmental resources engineering, Suny College of environmental science and forestry paper; 2015;68:1-30.

119. Moral A, Aguado R, Torrecilla JS, et al. Cellulose from Ulva sp. as a reinforcing fiber for the pulp and paper industry, 13th European Workshop on Lignocelluloses and Pulp; 2014.

120. Constante A, Pillay S. Compression molding of algae fiber and epoxy composites: Modeling of elastic modulus. Journal of Reinforced Plastics and Composites. 2016. 